\title{
Theological education in tropical Africa: An essay in honour of Christina Landman and a Kenyan perspective
}

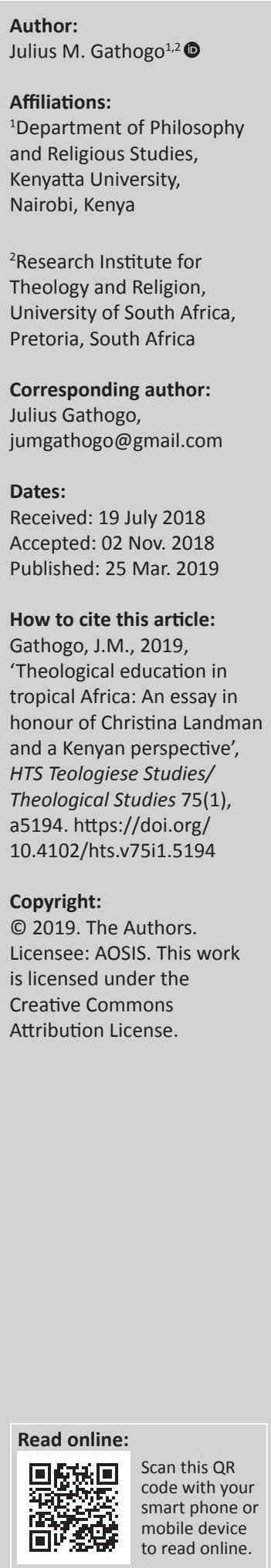

Christina Landman is a professor of Theology at the Research Institute for Theology and Religion, University of South Africa. As an East African serving under her as a research fellow at the Research Institute of Theology and Religion since 2014, and as somebody whose articles have been published in the two journals where she has been the editor, I can only honour her by contributing to her festschrift and in basing my reflections on my understanding of theological education in tropical Africa, where she plays a critical role - despite my bias towards East Africa, and Kenya in particular. In other words, the goal of this article is to focus on the future of theological education in Africa, with special reference to Eastern Africa, and Kenya in particular. How has Africa journeyed with theological education since its inception in the 19th and 20th century? How is it reflected in the academic institutions of higher learning, in ministerial training, in general academic contexts and in local congregations (churches)? Is it Africanity without ethics? Does it have a future? In addressing these concerns, the article employs historic-analytical design in its endeavour to assess the efficacy of theological education as an agent of social transformation in 21st-century Africa. Considering that Africa cannot be identified as a single geocultural context and/or as a monolithic entity, the article builds its case by mainly referring to the Kenyan context. Its methodology includes an extensive literature review of some materials that are connected to theological education, participant observation and personal reflections as an educationist in an African context. The methodology will also include the Protestant divinity school that was established in Frere Town, Mombasa, and later shifted to Limuru, Central Kenya, in 1929. It is set on the premise that the future of theological education in Africa is guaranteed by the growing interest in theological education among the youth, especially in the 21st century.

\section{Introduction}

When Professor Christina Landman visited Kenya, landing at Moi International Airport, Mombasa, at midnight on Monday, 20 November 2017, the principal of the Mombasa City-based college of theology and development, Bishop Hannington Institute, Dr Martin Olando, and I were there an hour earlier to receive this revered promoter of theological education in tropical Africa. I could not help but see Prof. Landman through two lenses, namely as the editor of two critical journals (Studia Historiae Ecclesiasticae [SHE]): Journal of Church History and Oral History Journal of South Africa [OHJSA]) and as a promoter of theological education in Africa. As an East African, and a Kenyan first, I can affirm that her two journals are some of the most consistent in terms of timely publications and have become reliable forums for our regional contexts. Indeed, since they became online journals 10 years ago (2008-2018), the voice of tropical Africa became clearer as they became the common medium of communication for a broader constituency. Put differently, in making them online journals, Christina Landman moved them to higher levels in theological and ecclesiastical studies, both in tropical Africa and globally.

In particular, I found the online platform a wonderful opportunity for expressing my personal and scholarly idiosyncrasies and indeed a forum where the Kenyan and East African oral histories have found a ready space and eventually triggered a broader debate for further action. I was encouraged to see Kenana Hotel and Restaurant in Kerugoya Town of Central Kenya, whose proprietor is a Kenyan literary scholar, Prof. Zachary Njogu Waita, renaming its very active relaxation hall as 'General Chui Wa Mararo Hall' after OHJSA published an article titled, '“Women, come and roast your own ram!" Recollections on Mau-Mau General Chui Wa Mararo (1927-1956)' in Volume 1 of 2013 (Gathogo 2013a). My articles on subjects such as the leadership prowess of Canon Johana Njumbi (Gathogo 2013b), the contribution of Milkah Muthoni Wambu as the 
pioneer gospel artist (Gathogo 2014c), the Mau-Mau war and the Church in Kirinyaga County of Kenya (Gathogo 2014a), Jesse Mugambi's pedigree and formative factors (Gathogo 2006), Nahashon Ngare Rukenya and turning points in social ecclesial history (Gathogo 2018), empire building and the church, money-wealth and church (Gathogo 2011), Pentecostalism and new religious movements (Gathogo 2011), theological institutions in Africa, methodology in church history (Gathogo 2008), the church and war (Gathogo 2014b), pioneer ecclesiastical leaders in colonial Kenya (Gathogo 2013a), women and the Mau-Mau war in Kenya (Gathogo 2017a), Albert Scweitzer's bilingualism (Gathogo 2017b) and the intrigues in the establishment of Mutira Mission (Gathogo 2012), among others, have seen scholars across the Mount Kenya region and beyond drawing their postgraduate research on the same topics and extending their respective scopes beyond my initial expectations. Through Landman's edited journals, my profile as a scholar in oral and ecclesiastical histories has gone beyond expectations. I can now conduct a simple web search and ascertain my influence as a modern scholar. Indeed, the online publications in both SHE and OHJSA have enabled some critical oral histories from tropical Africa to inspire a huge constituency of scholars and youths. In all this, Prof. Christina Landman deserves our collective compliments for making tropical Africa speak through the biggest library ever to emerge in world history, the Web. In view of this, these journals provided us with a forum to which we could refer our postgraduate students, as the need arises.

While on her five-day stay in Kenya, from 20 to 25 November 2017, Christina was able to deliver a pan-African lecture on 'Africanity and Ethics' at Pwani University on Wednesday, 22 November 2017. Even at the risk of appearing generic, she soldiered on to deliver a pan-African agenda in scholarship, as we listened attentively. This further crowned her as the de facto queen of theological and ecclesiastical education in tropical Africa, both South and North of Limpopo River. Her emphasis on ethics for researchers in Africa was indeed challenging, as she faithfully pointed out dangers inherent in unethical researches and indeed the future of tropical Africa. In other words, even at the danger of appearing universalistic as opposed to contextual, her Afro-optimism in theo-ecclesial education was perceptively delivered. This is also replicated in the cited journals, where her broad concern is to hear the diverse 'voices' of tropical Africa, rather than an exclusive South African voice.

As Martin Olando and I saw her off at Moi International Airport on 25 November 2017, we debated her short stay in Kenya. Eventually, we felt as if it were an ancestral return of the pioneer ecclesiastical and theological educators of the 19th and 20th centuries in disguised ways. In a continent where ancestors return in diverse and/or disguised ways, her reunion with us was of great importance, particularly as she enriched our conversation on critical concerns in theological education. Was her visit a reawakening call to take stock of our theo-ecclessial progress and eventually retrace our regional steps? This came out clearly when we recalled her visits to historical sites such as Fort Jesus, which was built by the Portuguese in 1593, as they sought to introduce Catholic Christianity in the 16th century before being ruthlessly stopped by Islamic advances. Was Christina relaunching theo-ecclessial studies in following the steps of pioneers such as Krapf, Rebman, Tucker and other early theo-ecclesial educators? Interestingly, Leven House, which hosted pioneer 19th-century European missionaries to East Africa (Ludwig Krapf and others), is just a two-minute walk from Fort Jesus, where Christina had a brief visit. Additionally, Darajani Hotel, Buxton, is a five-minute walk from where Krapf's wife, Rossina, and child were buried in 1844. Undoubtedly, Christina Landman's requests for more people to contribute to SHE \& OHJSA inspired the writing of this article. In other words, my writing prowess has been nurtured through the two journals where she is the editor. Additionally, her interest in understanding the Kenyan and East African theo-ecclesial historiographies was indeed challenging. In view of this, the article is also a by-product of her challenging talks during her November 2017 visit. It also serves to honour her general contributions in the world of academia.

\section{Stages of theological education}

Historically, we gather that there were several versions of theological education prior to the 19th and 20th-century European missionary explosion that ushered in a long-lasting wave that remains to date. One of these strands of theological education is that propounded by the early Church fathers and the Apologists before the 4th century CE. As Zablon Nthamburi (1991) concedes:

It is no wonder that North Africa produced theological giants such as Tertullian, St Augustine of Hippo and Cyprian; and indeed, Alexandrian Christianity produced apologists such as Clement, Origen and Athanasius. (p. 49)

In turn, the earlier version of theological education was tested by theological controversies such as those of Donatism and Arianism that punctuated it. It is saddening to note, however, that the rise of Islam in the 7th century CE changed the whole image as the forceful Islam from North Africa overwhelmed Christianity. As it attempted to usher in an orthodoxical theological position, the earlier version of theological education had to wrestle with the divergent and heretical positions of the time. Though it did not go far either, a second version of theological education in Africa was attempted in the 15th to 17th centuries by Portuguese explorers and missionaries (Muzorewa 1985:22). The third version of theological education in Africa is seen through the efforts of European missionaries of the 19th and 20th centuries.

It is the latter version of Christianity that made a real impact on Africa. Curiously, the planting of Christianity in the 19th century occurred simultaneously with colonisation, which has always made the scholars of religion wonder: were the colonial enterprise and the missionary enterprise related in any way? Did the cross follow the flag, especially with regard to English missions? Did they have a conspiracy 
after the Berlin conference of 1884-1885, which partitioned Africa? It is from there that African theologians emerged, such as John Mbiti, Bolaji Idowu, Edward Fashole-Luke, Gabriel Setiloane, Manas Buthelezi, Christian Gaba, Canaan Banana, Jesse Mugambi, Kwame Bediako, Emmanuel Katongole, Christian Baeta, Odupe Oduyoye, Harry Sawyerr, Lamin Sanneh, Jean-Marc Éla, A. Ngindu Mushete, Kä Mana, Desmond Tutu, John Pobee, Gwinyai Muzorewa, Boulaga Eboussi, Kwesi Dickson, Laurenti Magesa, Charles Nyamiti, John Mary Waliggo, Ezra Chitando, Jonathan Draper, Zablon Nthamburi, Tinyiko Sam Maluleke, Gerald West and Allan Boesak, among others. It is also since the 19th and 20th century mission theologies that African women theologians such as Denise Ackermann, Musa Dube, Christina Landman, Mercy Amba Oduyoye, Isabel Apawo Phiri, Esther Acolatse, Bernadette Mbuy Beya, Fulata Moyo, Anne Nasimiyu-Wasike, Eunice KaranjaKamara, Mary Nyanchama Getui, Grace Rose Imathiu, Philemona Njeri Mwaura, Musimbi Kanyoro, Elizabeth Amoah, Jane Nyambura Njoroge, Teresa Hinga, Kabamba Kiboko, Madipoane Masenya and Rose Teleki Abbey, among others, have emerged in the 21st century and have raised theological education to a gender-inclusive level.

To this end, 20th-century theological education culminated in both the liberation trend (whose chief proponents included Allan Boesak, Jean-Marc Éla, Manas Buthelezi and Desmond Tutu, among others) and the inculturation strand (whose key figures included Mbiti, Nthamburi, Idowu, Pobee, Banana, Alward Shorter and Bediako, among others). In other words, theological education in Africa was geared towards inculturation (dialogue between gospel and culture) versus liberation (a free society in the socioeconomic and political domains). At the end of the 20th century, a reconstructive thread in theological education emerged, as its chief proponents such as Jesse Mugambi, Ka Mana, Villa-Vicencio, and Elelwani Bethwel Farisani, among others, begun to advocate for the end of neocolonialism as they looked forward to the advent of a free postcolonial African worldview, devoid of all the problems of pessimism and defeatism.

In these post-apartheid and postcolonial times, the trend of Nehemiah's rebuilding of the Wall of Jerusalem and the insistence that theological education must be geared towards the reconstruction of the many 'African broken walls' (Mugambi 1995) became the vogue. Similarly, the African women theologians' feminist hermeneutical trend began at almost the same time as the reconstructive thread. In this, African women theologians, just as in the case of the latter, urged gender inclusivity as opposed to exclusivity. In view of this, the latter theologies of the 21st century have strongly addressed key concerns such as deconstruction of patriarchy, environmental management, negative ethnicity, racial divides, gender violence, men being battered by women (Gathogo 2015), postcolonial hermeneutics, gender inclusivity, xenophobia, education, reconstructive Christological hermeneutics, Afro-biblical hermeneutics, politics and post-colonialism in general, among other concerns. Regarding methodology, these theological trends have employed different tools, such as ideological readings of texts (Imathiu), narrative analysis (Njoroge), the use of minor and dominant paradigms in research (Gathogo), storytelling methods of analysis (Dube, Landman), autobiographical techniques (Kabamba Kiboko, Landman), oral techniques in research (Gathogo, Landman), documentation of historical and literary cases (Oduyoye, Mugambi, Mana), multidisciplinarity and mixedbag approach (Mugambi, Gathogo), use of available standard theological frameworks (Acolatse, Abbey, Ntloedibe, Farisani, Mugambi) and fieldwork research methods (Beya), among others.

With regard to a theoretical framework, the post-exilic motif (use of the Ezra-Nehemiah text) as opposed to the Exodus motif (use of Moses as the symbol of freedom) is critical for reconstructionists (Mugambi, Farisani, among others), feminist hermeneutics (Kanyoro), feminist theology, African women's theology, reconstructive motifs, post-colonialism, oral history, liberative, anthropological, social change theory, cultural theology, translatability theory (Sanneh), contextuality of Christian theology, the praxis model, the translation model, the anthropological model, the synthetic model, the transcendental model and the counter-cultural model (Bevans 1992).

\section{Holistic nature of theological education}

As noted thus, theological education in the 21st century Africa proceeds from the works of the 19th and 20thcentury European missionaries, who introduced a threefold ministry - that is, Christian ministry that incorporated basic education (through establishment of schools), healing (through introduction of dispensaries) and evangelisation (through building churches and reaching out to nonChristians). Apart from these explicit forms of the 19th and 20th-century missions in Africa, there are implicit forms, which include condemnation of some elements of African cultures as in the case of female genital mutilation, taking land for farming and for missions, and antislavery campaigns, especially on the East African coast. As the locals learnt how to read the Bible, and especially after the Bible was translated into the local African languages, theological education began to take shape in tropical Africa. Indeed, the current trends of theological education are a by-product of what Stephen C. Neil calls 'the heyday of colonialism', about which he quotes David Livingstone as having said:

I beg to direct your attention to Africa, I know that in a few years I shall be cut off in that country, which is now open. Do not let it be shut again. I go to Africa to try to make it an open path for commerce and Christianity. (Schapera 1961:59)

All in all, the nature of Christian education in Africa, as propagated in the 19th century CE by European missionaries, is well summed up by Dr David Livingstone as he describes how his wife, Mary, served the Bakwena of Botswana for 
11 years, from 22 January 1845 to about 1857 . To this end, Livingstone reported in 1846 thus:

Mrs Livingstone has recently commenced an infant and sewing school, but as it still possesses the attraction of novelty we cannot form an opinion as to the ultimate success of the measure. Paul and David continue to render valuable assistance in all our operations ... The infant school under the care of Mrs L. afforded us much encouragement. The attendance during the past year may be stated as from 60 to 80 . The failure of the native crops has lately had considerable effect on the regularity of their attendance, for the children have been obliged to go great distances in search of locusts and roots on which to subsist. Mrs L must also soon discontinue it for a season, but it will be resumed after her confinement. (Schapera 1961:59)

Thus, the Protestant missionary education, like the traditional African education, was holistic in that it did not only address metaphysical concerns but more importantly concerned itself with practical subjects such as day-to-day survival, dressmaking (tailoring), agriculture and stock keeping, among others. Indeed, as post-19th-century missionary Christianity took root, African Christianity began to emerge in its diverse fashions. It is a trend that continues to date, to the extent that even the Rev. Dr Ludwig Krapf, who was the pioneer Protestant missionary in East Africa, could not control it if he were to come back to his earthly life. Indeed, we have the African Instituted branch of churches, AfroPentecostal types (which incorporate elements of African culture and Pentecostal theology) and the revised missionary theology in the mainline churches (Catholics, Anglicans, Presbyterians, Methodists, Congregationists, etc.), where some elements of inculturation spiced with elements of Pentecostalism are visible, albeit not openly pronounced and/or proclaimed.

In my article, 'The birth of Protestant education in East Africa: Sampling Johannes Ludwig Krapf (1810 - 1881)' in SHE (Gathogo 2010:162-192), I have attempted to demonstrate the holistic nature of theological education that was propounded by the 19th and 20th-century missionaries to East Africa. In particular, I have cited the seven methodologies that the pioneer missionary in East Africa, Johannes Ludwig Krapf, used in his Protestant theological education: translating the Bible into local languages; schools as mediums of theological education; interest in knowing the locals; acting as interpreter and adviser to the King of Shoa; raising missionary enthusiasm in Europe through publications; consistency in his dream; and working more closely with the locals. Certainly, this educational trend continued among the missionaries and beyond. With schools coming up to train Africans to read the Bible in the late 19th and early 20th centuries, the need to begin formal theological studies, tertiary institutions and theological colleges also arose.

In particular, the Church Missionary Society (CMS) started St Paul's Divinity School at Frere Town, the settlement for freed slaves, near Mombasa City centre, on 06 July 1888, under the stewardship of Rev. E.A. Fitch. Fitch had come to Kenya (and East Africa at large) as Bishop Hannington's chaplain. He started the first Divinity class for the training of the African clergy there. As the then-CMS (Evangelical wing of the Anglican church) organising secretary of the area, Rev. W. S. Price noted that it was 'a red letter day in the history of the East African Mission' (Cole 2003:7) - as it showed that theological education had become part and parcel of working in East Africa, and Krapf's dream of an African church with a black bishop and with vibrant African Christians forming the huge congregation was turning out to be true. Price went on to say:

I do not know, but I cannot help feeling that even the Committee is not fully alive to the fact that the evangelization of Africa is to be done by Africans. (Cole 2003:199)

From there, Rev. (later Archdeacon) J.E. Hamshere continued with theological training from 1894 until 1925; through his stewardship, a few classrooms, the principal's residence and the chapel were built and dedicated in 1903. It was only in September 1929 when Rev. Canon Herbert John E. Butcher was appointed the principal of the Divinity School that had now moved from Frere Town (Mombasa) to Limuru near Nairobi, following the construction of the railway from Mombasa to St Florence (now Kisumu City), and had the first intake of theological students in January 1930, that the trend in theological education appeared to have stabilized for the better. Butcher was replaced in 1937 by Rev. Canon M.G. Capon (1938-1946). Capon was succeeded as follows: Rev. Stanley Good (1947-1953), Rev. Keith Cole (1954-1960), Rev. J. O. Welsh (1961-1967), Rev. Wilfred Stott (1968-1970), Rev. Bruce Gannaway (1970-1971), Rev. Dr Samuel Kibicho (1972-1974), Rev. John Riddlesdale (1974-1975), Rev. John F. Nyesi (1976-1977), Rev. Jeremiah Anondo (1978-1981), John Frederick Nyesi (1982), Roger Greeves (1983), Rev. Isaiah Muita (1984-1986), Rev. Enos Ashimala (1987-1990), Rev. Dr Elijah Mbogori (1991-1993), Rev. Dr Peter Ensor (19941998), Prof. Godfrey Nguru (1999-2005), Dr Timothy Wachira (2006-2010) and Rev. Prof. Joseph Galgalo (2010-2020).

Why focus on St Paul's Limuru? As a college for theological training, St Paul's becomes a critical reflection of theological education in Kenya and East Africa for various accounts. Firstly, it is presently a chartered private university since 2007 that offers courses beyond theology; hence, it offers holistic education - a trajectory that is in continuum with the previously mentioned European missionary trends. Its transformation from a mere divinity school in 1903 to a fullfledged university offering various academic disciplines such as Education, Business, Philosophy, Theology, Communication, Sociology and so on, demonstrates the holistic nature of theological education since the European missionary era in the 19th and 20th centuries. To demonstrate the holistic nature of theological education, the missionaries further introduced both agricultural education and modern medicine in schools. In particular, the Methodist missionary education goals were fourfold, namely, (1) academic training, (2) artisan training, (3) health training and (4) evangelical training (Nthamburi 1982:100). With regard to the need for teaching good agricultural methods, the purpose was to become self-supporting, especially where a mission had 
acquired a large piece of land around the mission centre. Because of the merging of theological education with other practical activities, Africans became suspicious of the missionaries. In particular, agricultural education was viewed with suspicion, as they feared a conspiracy between the settlers and the missionaries - to prepare them for cheap labour on European plantations. Nevertheless, the merging of theological education with agriculture, physical and social education and communication, among others, shows that the missionary legacy remains, even in the 21st century.

Secondly, with the appointment of Rev. Canon Herbert John E. Butcher as the principal of the Divinity School in September 1929 to lead the institution following its shifting from Frere Town to Limuru, a new chapter was opened. Rev. Butcher was a youthful, energetic Anglican priest who had served in Kenyan parishes, as priest in charge. Hence, he had the right experience to bring theory and practice together, especially as he led the theological institution. At Mutira Mission of Central Kenya, Butcher served with diligence and dedication. He became the first clergy to baptise the locals on 20 February 1920. He also saw the first confirmation service by a diocesan bishop (A.W. Peel of Mombasa Diocese) on 23 June 1923 (Gathogo 2011). From the CMS archives, we realise that after Butcher left Mutira Mission in December 1927 to pave the way for Rev. Hillard, he became the second and third principal of the Divinity School while it was still in Frere Town in 1928. When it was moved to Limuru, he was reappointed as the principal and served till the end of 1936. As noted, he was able to merge academic work with the fieldwork discourses; hence, theological education in Kenya began from a point of strength.

Thirdly, with Mildred Achola, from the Anglican Church of Uganda, becoming the first woman to enrol in theological education, and primarily for ministerial and/or ordination training, in 1976, women's place in ecclesiastical leadership, theological education and in ordination matters was boosted greatly. This was to pay dividends in the latter part of the 20th century and the 21st century, especially when ordination of women became the vogue in the 1990s after acrimonious debates in various Protestant churches, congregations, parishes and across various denominations. After Achola, women as theological students, tutors, lecturers, professors and administrators became the new trend. As such, Jane Nyambura (later, Dr Nyambura Njoroge) of the Presbyterian Church became the first Kenyan woman to train at St Paul's United Theological College for a Bachelor of Divinity from 1978 onwards. She also became one of the first lot to be ordained as clergy in the mainline churches in the 1980s. It was only in 1990 when the first woman lecturer, Deaconess Eugenia Adoyo, joined St Paul's staff. In 1999, Dr. Esther Mombo was appointed as the first woman academic dean in the institution, while Dr Emily Onyango was appointed the dean of students in 2000. Emily was replaced in 2002 by Rev. Alphama Kinyua. Achola's case thus marked a new turning point - the promotion of theological education among women (Onyango 2003).
Fourthly, since 1948 when St Paul's Divinity School was first referred to as a 'college', theological education has continued to move on to a higher level of articulation and has perpetually improved. In 1949, St Paul's Limuru succeeded in shedding its image as a mere Anglican theological college and opened to other Protestant bodies such as Methodists and Presbyterians, among others. Certainly, this ecumenical spirit, as seen in its multidenominational training, had been demonstrated much earlier, as noted above, though it went beyond there in 1949. In 1950, St Pauls College was for the first time referred to as 'United Theological College', though it was in 1955 when this new title was 'confirmed' and it was then owned by Anglicans, Methodists and Presbyterians. The three churches were later joined by the Reformed Church of East Africa in 1973. This strengthening of theological education was further boosted in 1959 when the Association of Theological Institutions of Eastern Africa (ATIEA) was inaugurated (Onyango 2003). The inauguration of an External London University Bachelor of Divinity degree in 1963 further boosted theological education, at least in the Protestant wing of the church.

Furthermore, the inauguration of the ATIEA, which for the first time allowed St Paul's College to offer its own Bachelor of Divinity degrees in 1978, was indeed a historical landmark. Why? This not only paved the way for the college (now university) to launch its diploma programmes in its satellite or affiliate colleges such as Berea-Nakuru, St Andrews Kabare, St Paul's Kapsabet and Bishop Hannington Mombasa, among other places, in 1989, but more importantly for St Paul's launching of its own Bachelor of Divinity programme in 1988. Again, the registration of the theological college by the government of Kenya, through the Commission of Higher Education, as a private university in 1989 was indeed a progression from both the External London degree arrangement of 1963 and the inauguration of the ATIEA degree arrangement of 1978. This progression further led to the final charter by the government of Kenya in 2007. And as the university website says:

On September 14, 2007, the University was awarded a Charter to become St. Paul's University. The University is based upon the partnership of the four Participating Churches and the NCCK [National Council of Churches of Kenya] as a corporate body with the representation in the Governing Council being ACK [the Anglican] 50\%, PCEA [the Presbyterian] 20\%, MCK [the Methodist] $10 \%$, RCEA [the Reformed] $10 \%$ and NCCK 10\%. (St Paul's 2018)

In St Paul's becoming a private university, theological and holistic education reached its climax; and indeed, the missionary labours were honoured dramatically. This progression of the former missionary societies of the 19th and 20th centuries forming their own ecumenical university was preceded by the Methodist missions (now Methodist Church), as an individual institution, when their Kenya Methodist University was officially authorised to operate as a private university in 1997. This came after they were given a letter of interim authority from the Commission of University Education (CUE) in July 1997. Similarly, the Presbyterian Church (formerly Scottish missions) followed suit. In 2007, 
the Presbyterian University of East Africa was given a Letter of Interim Authority by the CUE to start a university, and the first degree students were admitted in 2008. And despite the fact that the proposed Kenya Anglican University, based in Kanyuambora in Embu County, received a major infrastructural development boost after a US-based global trade and finance company pledged to give $\$ 61$ million, in 2017, the university is yet to pick up like the other cases mentioned (Muriithi 2018). Nevertheless, St Paul's remains one of the leading theological institutions in Kenya, with a rich history that builds on the rich legacy of the 19th and 20th-century missionaries in East Africa.

Fifthly, there has been a major shift from European missionary leadership at St Paul's Limuru to African leadership since 1972, when Samuel Gakuhi Kibicho was appointed as the first African principal. He was deputised by another African, Horace Etemesi, in leading St Paul's as a theological centre of the vast region of East Africa. This led to a major turning point in the history of theological education in sub-Saharan Africa. Although Prof. Kibicho had to 'flee' to Nairobi University after his theological position differed sharply with his colleagues, who were mainly European missionaries and expatriates, his two-year stay as the principal was equally a major turning point. In a nutshell, Kibicho's theological position is that there is a radical continuity between African religion and the Christian message. This continuity should be the starting point for African theology; and this requires a radical reinterpretation of the Christian concepts of salvation, revelation, evangelisation, Christ and other religions (Kibicho 1983:166-177).

In 1976, another African, Rev. John F. Nyesi, was appointed principal at St Paul's. He was succeeded by another African, Rev. Jeremiah Anondo, in 1978. In 1982, Rev. Nyesi was reappointed as principal, though he handed it over to Roger Greeves, a European missionary, in 1983. Again, Dr Peter Ensor, a Methodist missionary from Scotland, took over from 1994 to 1998, when Prof. Godfrey Nguru, a Kenyan, took over and set in motion the processes of accreditation to a full-fledged university, which ultimately happened in 2007, when he had already left to head another theological centre in East and Central Africa, Daystar University, in Nairobi. Nevertheless, Kibicho's pioneering role as a theological educator and as the first African principal shows that theological education in Eastern Africa has been owned by the indigenous people; indeed, the future of theological education could be predicted in the African region.

\section{Current trends}

The Zimbabwean theologian, Paul Gundani, wrote that the history of theological education in the African region has been characterised by 'foreignness, that is, foreign theological content, methodology, and languages'. He goes on to say that theological education in the African region 'has been captive to the North Atlantic worldview, and is showing little signs of struggle out of this form of oppression' (Gundani 2002:67-75). However, his observation is acceptable on the grounds that there are few books written by Africans themselves that purely address African Christology, African hermeneutics, African church histories, African soteriology, and African pneumatology, among others, without appearing to duplicate Western content and canon. In a conference on 'Legacies of Albert Schweitzer considered 1875-1965' that I attended from 14 to 16 October 2015, in Pretoria, South Africa, I was surprised to hear an African scholar insisting that contextualisation doesn't matter now. 'How do we talk of African context in light of oppression under the leadership in Zimbabwe [then under Robert Mugabe]? What is this contextualization all about?' he asked. For him, all regions of the world should pursue similar curricula in their theological education without focussing on the context; rather, human context is what matters. To me, this is intellectual arrogance that points to the influence of the 'foreign' theological resources that Africans consume in their libraries, the Internet, the archives and even in our oral discourses. After centuries of negative exteriorisation, the African situation may not want to 'risk' and venture into the theological unknown. In my view, there is a tendency for theologians and scholars in general to fear their colleagues whose theological positions appear openminded, liberal, more creative and broadly innovative. Such fears are expressed in diverse ways that include exclusion from leadership and timely promotions and bad-mouthing, among other manifestations. The better way is to seek scholarly fellowship and eventually learn from one another. Such forms of mediocrity speak volumes about the huge gaping holes in our scholarly prowess. Certainly, a society that punishes competency and rewards mediocrity without an iota of shame is a decaying society.

When we compare, for instance, the Black Theology of South Africa and the Black Theology of North America, we discover that both theological players and consumers are all black Africans who express their misfortunes of oppression in light of the Gospel of Christ. In the South African case, before the dismantling of apartheid, the key concern was apartheid and its resultant racist segregation, oppression, domination and its colonialist tendencies. With regard to the Black Theology of North America, James Cone, the chief proponent, specifically addresses the racial concern and not necessarily racial segregation. In the US, there are no clear policies on racial segregation as there were in South Africa during the era of apartheid, or before 1990. After apartheid, African theological concerns in South Africa, as in the rest of the tropical Africa, tilted towards reconstruction, rebuilding, economic rejuvenation, reconstructive hermeneutics, theological reconstruction, rewriting of African histories, inculturation and so on. If looked at through the same lenses, the African situation in the US and Africa can wrongly and easily be seen as just the same. In my view, however, African Women's Theology is the most vibrant theological trajectory, which matches with the concerns of reconstruction theology, and which was first introduced to the afro-theological scene in 1990. In a nutshell, African Women's Theology was born in 1989 after Mercy Oduyoye gave a keynote speech that called for a two-winged theology of men and women. Nevertheless, 
the concerns for the latter theologies are largely the same. That is, deconstruction of patriarchy, HIV and AIDS, education, environmental concern, cultural hermeneutics, societal reconstruction along gender lines, liberation of African women and so on (Gathogo 2008:23-62). Their methodologies (including comparative analysis, storytelling, inclusivity quests and critical re-evaluation, among others) are largely the same.

While theological education in South Africa is mainly done in public universities, where researching lecturers easily receive government subsidies in order to promote it, the Kenyan (or East African) case is different. Indeed, theological institutions for ministerial formation are virtually private universities or seminaries, such as St Paul's (discussed above), Africa Nazarene University, Daystar University, the Pan-African Christian University, the Kenya Methodist University, the Presbyterian University of East Africa, the Catholic University of Eastern Africa, the Scott Christian University, the African International University and the emerging Anglican University, among others. Does it mean they offer inferior education owing to the lack of government subsidies that ought to fund their research or pay lecturers? Considering that volunteer missionaries from the north are largely seen as influencing theological education, does it mean they offer Christian theology in Western theological garments? Considering that various theological textbooks are bought - sometimes donated - from the Western world, does it mean theological education in Africa is badly compromised and irrelevant to the African people? Such questions need further review.

Concerning theological journals, where South African students are encouraged to quote recently published books and more importantly, the theological journals - the East African context, as I see it, largely clings on to the old textbooks. Why? The culture of referring to refereed journals is not emphasised, owing to the shortage of active peerreviewed journals, as in the case of SHE and OHJSA. In Kenyatta University, which is a public university, the journal of humanities (ChemChemi, covering various disciplines where theology and religion is a part) takes a long time before it produces an edition. This means it is not reliable for either the lecturer or the student; hence a person cannot bank on it for new information, new methods of learning or new content in theological and religious education. The same scenario continues even in the private universities and seminaries. In some remote cases, however, there are active academic journals for theological education. One is the Africa Theological Journal, founded in 1968 in a Lutheran context in Tanzania, and the Africa Journal of Evangelical Theology, founded in an evangelical setting in Kenya since 1982. The latter journal is owned by Scott Christian University, Machakos. In the Roman Catholic wing of the East African church, Hekima: Journal of Humanities and Social Sciences has continued to build theological education continuously. In turn, Hekima Review is the official journal of the Jesuit School of Theology, Hekima College, a campus of Catholic University of Eastern Africa. It is published biannually. With a few others, such refereed journals have consistently remained in the market even though they have their own challenges as well. Without credible journals to rely on and without a clear-cut culture of researching through refereed journals, our theological students and theological education in East Africa, in general, remain wounded entities.

With regard to the textbooks, the same unfortunate scenario that informs the academic journals applies. Academic books that are published in the West, irrespective of their cultural contents, remain the 'better' and more commonly used books in our class instructions. Likewise, the lack of credible marketing and distribution of books that are published locally discourages African writers from 'getting into the risk'. Undoubtedly, the postcolonial reconstruction phase in Africa requires theological education that is technologically driven, in line with the 21st-century skills movement in education. It requires theological education and/or any other form of education to set in place a curriculum that makes an attempt to solve the myriad (African) problems such as ethnic bigotry, xenophobia, corruption, HIV and AIDS, leadership, social hermeneutics, youth and students, gender relations, cults and sects, poverty, family, education, the boy-child as an endangered species today, the girl-child and education, family and values, violence and intolerance, men battering and new forms of domestic challenges, and terrorism and other aspects of survival. In my view, thus, every theologian has to be necessarily provincial, though kerygmatically universal, in the sense that one has to theologise within his or her situation and context - as God's revelation is not necessarily universalised.

In the Old Testament, God spoke to Moses and tasked him to lead the revolution geared towards the justice of the oppressed Hebrews. Similarly, God called Nehemiah and tasked him with the work of reconstruction of the barricading wall of Jerusalem, and not necessarily to reinvent the wheel. There are those whose emphasis is on triumphant theology (afro-Pentecostals in particular), based on Jesus descending from Mount Olives as he moved triumphantly towards Jerusalem (Mt 21:1-11; Lk 19:28-44). This pre-Easter theology and/or Palm Sunday Theologians are common in East Africa, as televangelists, and are growing hugely influential, and almost eclipsing conventional mass and written theologies. Certainly, there are others in the East African theological market who take Jeremiah's trajectory of 'uprooting and then planting afresh' and other forms of oral theologising. There are others, mainly oral and symbolic theologians, who have taken the Pauline methodology of embracing suffering as a gift of the Holy Spirit and as a critical tool of mission in hardship areas. To such, they become weak in order to win the weak - a trajectory based on 1 Corinthians 9:22 where Paul says, 'To the weak, I became weak, that I might win the weak. I have become all things to all people, that by all means I might save some'. With a hotchpotch of theological trajectories in the various regions of tropical Africa, theological tasks will include addressing the diverse commonwealths (refer to anglophone, lusophone, arabophone and francophone) without ignoring the resultant contextual and 
historical issues that are critically important. This broad diversity in theological education is compounded by the huge number of priests who study abroad and then return to Africa with smart degrees, only to fail miserably when they try to apply their newly acquired education skills to the local congregations. In some quarters, they are seen as irrelevant, elitist, proud, out of touch with reality or not theologically educated at all. Does this amount to the Africanity without ethics that Christina Landman propounded at Pwani University in November 2017 when she addressed the Kenyan scholars? If we conduct our scholarly discourses unethically, more theo-academic robots will increase in our East African region and in the rest of tropical Africa. Clearly, unethical aspects of our scholarly work manifest themselves in the duplicity of old materials, harassing and demoting the most illustrious ones, 'compiling' data before research itself is conducted, using irrelevant books and journals, giving outdated reference books to our students, falsifying data and employing unorthodox methods in research and in general education. Clearly, the question of Africanity without ethics has to be addressed in our East African region and in the rest of tropical Africa. Prof. Christina Landman has ably demonstrated her dislike for Africanity without ethics, a lesson that necessarily informs all.

\section{Conclusion}

The article began by recalling the critical role of Christina Landman as a leading African theologian, Church historian and editor of two powerful journals of theo-ecclesial education. It went on to explore the various versions of theological education prior to the 19th and 20th-century Protestant missionary explosion, especially in East Africa. In particular, Portuguese Christianity and their resultant theologies of trade and gospel failed. Equally, the earlier version of Christianity that was propounded by the church fathers, which was ironically rich theologically, equally failed after the birth of Islam in the 7th century. The article also demonstrated the holistic nature of theological education that is, education that addresses not just the spiritual realm but also physical needs such as agriculture, carpentry, building, trade, economy, politics and so on. This holistic approach is partly a missionary legacy and a carryover from the African religious heritage. On the whole, the future of theological and ecclesiastical education in Africa lies in reconstruction and in employing ethical Africanity. By this, I mean efforts towards inculturation, use of relevant academic journals, use of technological resources, credible oral sources, contextualisation, retraining of human resources, inclusivity and a multidisciplinary approach in theologising. While St Paul's Limuru has been used as a case study where a union of some churches formed a divinity school that eventually graduated into a university in 2007, the new trend of each Christian denomination starting its own seminary and/or university without adequate funding or resources will only increase theological marginalisation, as he who pays the piper calls the tune. Seen in this way, Africa may continue to consume Western literature if Africanity without ethics remains our defining characteristic. In other words, the way forward is to strengthen the existing theological institutions for learning rather than each denomination opening its own theological institution. Indeed, as Afro-Pentecostalism theology and its resultant discourses overshadow the mainline churches in the 21st century, I expect to hear of more universities and seminaries being established by the former, thereby compounding the matter further. The end result is that more theological fragmentation will be visible, and more theological compromise on quality will be experienced. The tropical Africa, East Africa in particular, must indeed awaken to this fact. Unless we strengthen the existing theological institutions by merging some institutions, regardless of whether we are Afro-Pentecostals, Anglicans, African Instituted or Congregationalists, failure to address this challenge of Africanity without ethics in our theological formation will amount to self-destruction. As we recall the critical contribution by Christina Landman, as a scholar in theo-ecclesial education, it is equally important to understand our regional theo-ecclesial contexts and act appropriately. We must now swing into action and do something.

\section{Acknowledgements}

I wish to thank the Research Institute of Theology and Religion for their research input and research incentive in October and November of 2017 that largely enabled me to research this topic. Indeed, this wonderful opportunity for research and publication was financially oiled by their research input, where Prof. C. Landman played a critical role.

\section{Competing interests}

The author declares that he has no financial or personal relationships that may have inappropriately influenced him in writing this article.

\section{References}

Bevans, S., 1992, Models of contextual theology: Faith and cultures, Orbis Books, Maryknoll.

Cole, K., 2003, “'O St. Paul's ... If I forget Thee!"', in E. Onyango (ed.), For God and humanity: 100 years of St. Paul's United Theological College, Zapf Chancery, Eldoret.

Gathogo, J., 2006, 'Jesse Mugambi's pedigree: Formative factors', Studia Historiae Ecclesiasticae XXXII(2), 173-205.

Gathogo, J., 2007, 'Story-telling as a methodology in developing a theology of reconstruction', Studia Historiae Ecclesiasticae XXXIII (1), 155-186.

Gathogo, J., 2008, 'Genesis, methodologies, and concerns of African theology of reconstruction', Theologia Viatorum 32(1), 23-62.

Gathogo, J., 2010, 'The birth of Protestant education in East Africa: Sampling Johannes Ludwig Krapf (1810 - 1881)', Studia Historiae Ecclesiasticae, South Africa, (December 2009, XXXV Supplement), 167 - 192.

Gathogo, J., 2011, Mutira Mission: An African church comes of age, 1912-2012, Zapf Chancery, Limuru.

Gathogo, J., 2013a, 'Johana Njumbi (1886-1991): The pioneer African leader in Mutira Mission', The Oral History Journal of South Africa 1(1), 74-95. https://doi. org/10.25159/2309-5792/1596

Gathogo, J., 2013b, 'Unsung heroes and heroines at Mutira Mission, Kenya (1907-2012)', Studia Historiae Ecclesiasticae 39(1), 107-127.

Gathogo, J., 2014a, 'Mau-Mau War and the Church in Kirinyaga, Kenya: Accounting for the tension and conflict (1952-1960)', Studia Historiae Ecclesiasticae 40(2), 19-41.

Gathogo, J., 2014b, “"Women, come and roast your own ram!” Recollections On MauMau General Chui Wa Mararo (1927-1956)', The Oral History Journal of South Africa 2(1), 102-120. https://doi.org/10.25159/2309-5792/1586 
Gathogo, J., 2014c, 'Extremist or an inculturationist? Retrieving Milkah Muthoni's (1948-2009) afro-Pentecostalism', Studia Historiae Ecclesiasticae 40(1), 191-214.

Gathogo, J., 2015, 'Men battering as the new form of domestic violence? A pastoral care perspective from the Kenyan context', HTS Teologiese Studies/Theological Studies 71(3), 1-9. https://doi.org/10.4102/hts.v71i3.2795

Gathogo, J., 2017a, 'Mau-Mau War Rituals \& Women Rebels in Kirinyaga County of Kenya (1952-1960): Retrieving women participation in Kenya's struggle for Independence', Studia Historiae Ecclesiasticae 43(2), 1-16. https://doi.org/ 10.17159/2412-4265/2017/1822

Gathogo, J., 2017b, 'Bilingualism in Albert Schweitzer's works and its relevance for Africa', The Oral History Journal of South Africa 4(1), 46-58. https://doi. org/10.25159/2309-5792/1795

Gathogo, J., 2018, 'Nahashon Ngare Rukenya and the moral re-armament in Kenya: The turning point and the resettlement of post war victims (1959-1970)', Studia Historiae Ecclesiasticae 44(2), 1-16.

Gundani, P., 2002, 'The state of theological education in Southern Africa: Issues and concerns', Ecumenical Formation 98(99), 67-75.
Kibicho, S.G., 1983, 'The teaching of African religion in our schools and colleges and the Christian attitude towards this religion', African Theological Journal 10(3), 29-37.

Mugambi, J.N.K., 1995, From liberation to reconstruction: African Christian theology after Cold War, EAEP, Nairobi.

Muriithi, K., 2018, 'Kenya Anglican University to gey Sh. 60.8 billion grant', Education News, 07 April, 2017, viewed 25 October 2018, from http://educationnews.co. $\mathrm{ke} / 2017 / 04 / 07 /$ kenya-anglican-university-to-get-sh60-8-billion-grant/

Muzorewa, G.H., 1985, The origins and development of African theology, Orbis, Maryknoll.

Nthamburi, Z., 1982, A history of the methodist Church in Kenya, Uzima, Nairobi.

Nthamburi, Z., 1991, The African Church at the crossroads, Uzima, Nairobi.

Onyango, E. (ed.), 2003, For God and humanity: 100 years of St. Paul's United Theological College, Zapf, Eldoret.

Schapera, I., 1961, Livingstone's Missionary Correspondence, 1841-1853, Chatto \& Windus, London.

St. Paul's, 2018, 'Our History,' viewed on 13 April 2018, from http://www.spu.ac.ke/ old/spu/our-history.html 